\title{
Et ve Balık Kurumu Ankara Kombinasında Kesilip Piyasaya Arzedilen Parça-Paket Etlerin Hijyenik Kalitelerinin Mik- robiyolojik Yönden Analizleri Üzerinde Araştırma*
}

The Research of The Analysis for The Microbiological Quality of Pre-Packed Meat Which Were Prepared and Marketed by The Meat and Fish Organization in Ankara.

\section{A. Cemâl OMURTAG** Sevinç TƯRKER***}

\section{GIRIȘ}

Bugün, insanlı̆̆ın en önemli sorunlarından birisi beslenme konusudur. Günümüzde, nüfusun hızla artı̧̧ı, buna karşılık doğal kaynakların sınırlı oluşu bu problemin, çözümünü daha güç bir hale sokmaktadır.

Bu nedenle, beslenme sorununun çözümünde Ulusların ve Uluslararası kưuluşların üretim artışına dönük çabaları yoğunlaşmışır.

Ancak, beslenmede gidaların yeterlilimi kadar, dengeli bir şekilde tüketilmesi de önemlidir. İyi bir beslenmede en önemli husus dengeli beslenme prensibinin gözönünde tutulmasıdır. Dengeli beslenmede hayvansal proteinin orantısı özellikle önem taşımaktadır. Her bir kilogram canlı ağırlık için günde 1 gram protein alınması gereklidir. Ancak bunun 1/2 sinin hayvansal kökenli proteinlerden karşılanması zorunludur. Yeterli ve dengeli bir beslenmede hayvansal proteinli gıdaların tüketimi uluslararası gelişmişlik veya az gelişmiş-

Redaksiyona verildiği tarih: 13 Nisan 1978.

* Seving TURKER' in "Et ve Balık Kurumu Ankara Kombinasinda kesilip piyasaya arzedilen parga-paket etlerin hijiyenik kalitelerinin Mikrobiyolojik yönden analizleri üzerinde araştırma" isimli doktora tezinin özetidir. Sivnav tarihi : Ocak 1977. versitesi.

** Mikrobiyoloji ve Besin Analizleri Kürsüsü, Eczacılık Fakültesi, Ankara Úni-

*** TỦBITAK, Uygulayıcılarla ilișkiler ünitesi, gıda uzmanı Ankara. 
lik ölçüsü olmuştur. Bir batılı, günde kişi başına 80 gram hayvansal protein tüketirken, az gelişmiş ülkelerde bu miktar 10 gram dolaylarında ve hatta hiç denecek kadar az bulunmaktadır. Ülkemizde ise, hayvansal protein tüketiminin kişi başina sadece 19 gram olduğu production Year Book FAO 1971 (10) de açıllanmış bulunmaktadir. Bu durum da Ulusumuz tüm olarak ele alındığında yeterli ve dengeli bir beslenmeden yoksun olduğu açik bir şekilde görülmektedir.

Hayvansal besin maddelerinin üretiminin artırılması yaninda bunların hijyenik kalitelerini koruma ile birlikte tüketime değin depolama koşullan da gereği gibi yapılmahdır. Bunun için besin maddesinin tüketicinin eline ulaşıncaya kadar ki bu safhada, kontrollarının tam bir düzen içinde sürdürülmesinin temini de Hükümetlerin görevi arasindadir.

Günlük tüketim maddesi olan etin işleme kademelerinde, etkili bir kontrol sistemine tâbi tutulmaması halinde, halk sağlığı tehdit edilmiş olduğu gibi, kyymetli bir besin maddesi olan etin de, mikroorganizmalar aracılığıyle dekompozisyona uğrayarak, besin değerinin düşmesine ve hatta insan sağlığının tehlikeye sokulmasına neden olur.

Sağlık ve Sosyal Yardım Bakanlığı Gıda Maddeleri Tüzüğü (16) etlerin hijyenik kalite kontrolu ile ilgili olarak bir standard vermediği gibi, laboratuvarlar arasında da bu konu ile ilgili bir metod beraberliği yoktur.

Sonuç olarak "Etlerin hijyenik kalitesinin mikrobiyolojik yönden analizi" konulu bu araştırma da, halkımızın gereksindiği hayvansal proteinin, mikroorganizmalara bağh kalite düşüklüğünü saptamak ve etlerin piyasaya çıkarılması için çalışma aşamalarına ait mikrobiyolojik standardların saptanmasında yararlanılması amaçlanmıştır.

Genel olarak et denildiği zaman koyun, sığır, kümes hayvanlar1nın ve bazı kuşların yenebilen iskelet kasları ile balık eti tanımlanmış olur. Kasaphk hayvan eti deyiminden; sıcak kanlı hayvanların sakadatı (iç organları) dışında insanlar tarafindan yènebilen kısmı anlaşıılır.

Genel olarak iskelet kasları kasaphk hayvan ağırlığının \% 40-60 inı oluştururlar. Yukarıdaki tanımlamaya giren et ise hayvanların sadece çizgili kaslandır. Çizgili kaslarda birinci ünite kas lifleri (myofibril), ikinci ünite ise birden fazla kas lifinin birleşmesiyle meydana 
gelen kas demetidir. Çizgili kaslar (İskelet Kasları), kas liflerinin bağlayıcı bir doku aracılı̆g ile birbirine paralel olarak dizilmesi sonucu oluşur.

Kas proteininin yapısı \% 67-78 myosin, \% 21 globulin, \% 10 myogen, $\% 1$ myoalbumin ve $\% 1$ den daha az olarak kas hemoglobininden oluşmaktadır. Bir kas da bulunan inorganik maddelerden potasyum, kas dokusunun başlıca katyonudur. Ancak sodyum, magnezyum, kalsiyum da kas dokusunun diğer katyonlarını oluşturur. Esas anyon olan fosfat ise ATP (adenozintrifosfat), ADT (adenozindifosfat) ve fosfokreatin halinde bulunur. Diğer anyonlar ise klorür ve iz halindeki sülfat'lardan oluşur.

Vücudun en son gelişen kısmı olan yağ dokusu \% 99 trigliserid çok az miktarda fosfo lipid, sterol, karotin ve yağda eriyen vitaminlerden oluşmaktadır.

Et, kimyasal yapısı bakımından mikroorganizmaların üremesi için çok uygun bir ortamdir. FRAZIER (4) çiğ etin kendi enzimleri ile ve mikroorganizmaların etkisiyle çok çabuk değişikliğe uğradığını bildirmiştir. Enzimlerin etkisiyle şekillenen bu değişme tabiatı itibariyla kimyasal bir değişmedir. Ette meydana gelen bu değişmelerden söz edilirken et yağının oksidasyonu sonu yağda meydana gelen değişmeler de birlikte müteala edilir. Etlerde bekletilmek suretiyle meydana gelen otolizis, gerek sığı etinde ve gerekse av hayvanlarımı etlerinde arzu edilen bir husustur. Ancak etlerin kesiminden sonra belirli bir süre bekletilmesi suretiyle olgunlaşma olayı su ürünleri için bozulmaya neden olur.

Ette meydana gelen otolitik değişmeler kas dokusundaki proteinin, proteolitik enzimler aracılığı ile proteolizis olayr yağ dokusunda ise, lipolitik ve oksidatif enzimlerin aktivasyonu sonu lipolizis olay' şeklinde ortaya çıkar. Bu enzimatik olayların ilerlemesi yağların dansitesi, proteinlerin de dekompozisyonuna yol açar. Mikroorganizmalara bağlı bozulmalara proteolitik ve lipolitik mikroorganizmalar neden olur. Proteolitik mikroorganizmalara örnek olarak Bacillus, amarus, Bacillus coagulanse, Bacillus thermophilus gibi spor veren aeroplar ile Pseudomonas türleri, Micrococcus caseoliticus, Strep. liquefaciens, Strep. lactic ve Lactobacillus casei'yi verebiliriz, 
Etlerin dekompozisyonuna neden olan mikroorganizmalar etlerin kesim ve parçalanmaları esnasında dış ortamdan ve bağursak muhtevasından bulaşurlar. Bundan başka etin parçalanması esnasında kullanulan çeşitli aletler ile parçalama işi ile görevli personel, havadan, etlerin taşındığı arabalar etlerin konduğu kutular olmak üzere bir çok araç ve gereç etlerin mikrobiyolojik kontaminasyonuna(bulaşmaya) yol açar. liriz.

Dokularda, bu kontaminasyonun nedenlerini şöyle suralayabi-

1- Bağırsaklar çok dolu iken kesimleri yapılmıs hayvanların dokuları, daha çabuk ve daha fazla miktarda mikroorganizma tarafundan istilâ edilir. Bưnu önlemek için hayvanların kesimden evvel aç bırakılmaları gereklidir. Bu aç bırakılma süresinin 24 saat olmasını önerenler dahi vardır.

2- Ateşli bir hastalık seyrettiği süre içinde kesilen hayvanlarda etin dayanma süresi kısalarak dekompozisyonun hızı artar.

3- Bakterilerin üremesinde kesim metodu ve kesimden sonraki kan akıtma işlemininde rolü önemlidir. Kanın iyi akıtılması etin bozulmasım geciktirdiği gibi, etin kalitesinin bozulmadan iyi bir şekilde muhafazasını da sağlamış olur.

4- Soğukta muhafaza işleminin gereği gibi yapılması mikroorganizmalarmn üremesini engeller. Hızlı ve aşağı derecelerde soğutma, mikroorganizmaların üremesini geçiktirir. SKOVGAARD (13) kesiminden sonra gövdelerin bakteriyel kontaminasyonu ile ilgili olarak mezbahaların büyüklüğü ve küçüklüğü gözönüne alınmaksızın aşağıdaki temel hijyenik koşulları önermiştir.

a) Karkaslar kesimden sonra gövdenin yerden temasinı kesen ray üzerinde taşınmalıdır.

b) Deriler kesimden sonra hemen gövdeden ayrılmalıdır.

c) Bağırsaklar patlatılmadan hemen gövdeden ayrılmalıdır.

d) Kesim esnasinda plastik elbiseler kullanilmalı ve bunlar her kesimde değiştirilmeli, yeniden yıkanip dezenfekte edilmeden tekrar kullanılmamalıdır,

e) Islak etin hemen doldurulmaması halinde kuru ete oranla dekompozisyon çok süratle oluşacağından, karkaslar yüksek basınçlı su ile yıkanmalidir. 

lidir.

f) Mide ve bağırsaklar, karkasın yüzüldüğü yerde açılmama-

g) Görevli personelin dışında hiç kimse kesim salonuna alınmamalıdır,

h) Köpekler mezbahalara yaklaştırılmamahdır.

WESOLOWSKI, KOBA ve CHARCZUK (18)'nin, 1969 yılında yaptıkları araştırmada et ve et mamüllerine bağlı olarak, 141 kişinin zehirlendiği, zehirlenmenin Salmonella typhimurium' dan ileri geldiğini saptamışlardır.

LAZZARA ve PRIOLA (7) Salmonella'lar ile kontamine taze etin insanlarda zehirlenme meydana getirdiğini saptamışlardır.

VAN SCHOTHORST ve KAMPELMACHER (17), 278 et numunesinde yaptıkları Salmonella taramasinda \% 34.7 oraninda Salmonella genusuna ait muhtelif speciesler izole etmişler, bunun nedeni olarak da mezbahaların kesim esnasında hijyenik çalışmaması sonucu kontaminasyonun vukua geldiğini saptamışlardır.

ZAGAEVSKY (19), gövde, kas, iç organlar ve lenf yumrularında Staphylococcus bakımından yaptığı araştırmada özellikle lezyonlardan bol miktarda Staphylococcus izole etmiştir.

PANAGITOPOULOS ve SPANOS (9)'in ette yaptıkları total bakteri saymminda; ortalama olarak bir gram 10-10 $0^{4}$ mikroorganizma tespit etmişlerdir.

GULUSTANI (5) gövde etler üzerinde Salmonella, E. coli ve Enterococcus ile ilgili olarak yaptığı çalışmada hiçbir Salmonella species'i tespit edememişlerdir.

SINEL ve KUSCH (12): Karkas ile parçalanmış gövde ve paket halinde hazırlanmış etler üzerinde Total bakteri sayımi ve Enterotoxigenic Staph. üzerinde yaptıkları çalışmada numunelerin sadece \% 12 sinde Enterotoxigenic olmayan Staphylococcus türleri izole etmişlerdir.

TIMONEY ve WHELAN (15) 200 adet et numunesinin Salmonella genusuna dahil spesiesler ile, kontaminasyonu üzerinde yaptıkları araştırmada \% 4.5 oranında Salmonella spesies'leri ile kontamine olduklarını tesbit etmişlerdir. 
IONESCU, INENISTEA ve IONESGU (6); 156 polietilen torba içinde dondurulmuş domuz eti üzerinde Salmonella genusuna dahil spesies'lerin varlığı bakımından yaptıkları bu araştırmada 12 ayrı Salmonella spesies'i izole etmişler, ayrıca bunların etlerin parçalanması esnasında vukua geldiğini belirtmişlerdir.

ZAGAEVSKII (19) 312 et numunesi üzerinde Staphylococcus'lerin etlere kontaminasyonu açısından yaptığı çalı̧̧mada kesim salonundan aldığı 76 et numunesinde Staphylococcus tespit etmiştir.

TIECEO, (14) Kiymalarda Total bakteri sayımı, Enterococcus, Staphyloccus, E. coli ve Salmonella türleri ile ilgili olarak yaptığı mikrobiyolojik araştırmada kontaminasyona el ile işlemenin neden olduğu, Salmonella türleri hariç Enterococcus, Staphylococcus ve E. coli ile total bakteri sayısi'nun el ile işleme süresine bağh olarak yüksek oranda bulunduğunu saptamıştır.

MATERYAL ve YÖN'TEM

A- MATERYAL:

Bu çalışmada, Et ve Balık Kurumu, Ankara Kombinasında 11.5. 1972 ile 16.3.1974 tarihleri arasında parça-paket et halinde işlenen 200 adet gövdeye ait et numunesi materyal olarak kullanılmıştır.

B- YÖNTEM:

Numunelerin alınmasi: Numuneler kesim yerinde piyasaya arz edilmek üzere olan etlerden steriliteye uyularak laboratuvarda ekimleri yapılmak üzere alınmıştır.

Numunelerin Ekim için hazırlanması: Numunelerin dilüsyonları OMURTAG (8) tarafindan bildirilen stok buffer solüsyonu ile yapilmiştır.

Ana dilüsyonu hazırlamak için numune etten 10 gram alınmıs, steril bir havanda bir miktar sulandirma sıvisı ile iyice ezilerek emülsiyon haline getirilmiş ve steril sulandırma sıvısı sulandırma şişelerinde 100 c.c. ye tamamlanarak iyice çalkalanmışlardır. Ekim için; 1/10 ilâ $1 / 10000$ dilüsyonlar kullanılmıştır. 
A) Total Bakteri miktarının saptanması:

AMERICAN PUBLIC HEALTH ASSOCATION (1) de verilmiş olan teknik ve yöntem modifiye edilerek bu araştırmaya adapte edilerek uygulanmıştır.

B) Koliform grubu mikroorganizmaların saptanması:

Bu amaç için AMERICAN PUBLIC HEALTH ASSOCATION (1) tarafindan bildirilen Violet Red Bile Agar Besi yeri ile buna ait teknik ve yöntem uygulanmıştır.

C) Maya ve Küf sayımı:

Bunun için DIFCO (3)'nun Potato Dextrose Agar besi yeri kullamılmıs teknik olarak da AMERICAN PUBLIC HEALTH ASSOCATION (1) tarafindan bildirilen teknik ve yöntem uygulanmıştır.

D) Str. faecalis miktarının saptanmasi:

Str. faecalis miktarının saptanmasında REINBOLD, SWERN ve HUSSONG (11) tarafindan önerilen teknik ve yöntem uygulanmiştır.

E) Enterotoksijenik Staphylococcus'lerin miktarının saptanması:

Bu amaç için CARTER (2) tarafindan övülen yöntem uygulanmıştır.

F) Salmonella-Shigella genusuna dahil bakteri spesies'lerinin saptanmasi:

Bunun için DIFCO (3)'nun SS Agar besi yerinden yararlanılmıştır.

\section{SONUÇ}

Bu çalı̧̧mada, Et ve Balık kurumunda üretilerek piyasaya sunulabilir hale getirilen, parça-paket etlere, besin hijyeni yönünden mikrobiyolojik analizler uygulanmıştır.

Et mamüllerine oranla, etin daha fazla tüketilmesi; bu çalışmada et mamülleri yerine, taze et üzerinde çalışılmasına neden olmuştur. 
Ưlkemizde, bugüne kadar etler üzerinde mikrobiyolojik yönden sistematik bir analiz uygulandığına dair herhangi bir literatür bilgiye rastlanmamıştır.

Koliform grubu mikroorganizmaların sayımında 200 numunenin 56 's1 pozitif bulunmuştur.

Enterococcus yönünden analize alınan numunelere ait sonuçlar Cetvel (1) de verilmiştir.

$\mathrm{Bu}$ araştırmada işlenen numunelerin toplam analiz sonuçlar,

6 Numarah Cetvelde Kaydedilmiştir.

\begin{tabular}{|l|c|c|c|c|}
\hline $\begin{array}{c}\text { Aranan } \\
\text { Bakteri türü }\end{array}$ & $\begin{array}{c}\text { Işlenen } \\
\text { numune sayısı }\end{array}$ & $\begin{array}{c}\text { Pozitif } \\
\text { numune sayısı }\end{array}$ & $\begin{array}{c}\text { Pozitif numune } \\
\text { Yüzdesi \% }\end{array}$ & $\begin{array}{c}\text { gramdaki } \\
\text { bakteri mik- } \\
\text { tarı ortalaması } \\
\text { oral Bakteri }\end{array}$ \\
\hline $\begin{array}{l}\text { Total } \\
\text { sayımı }\end{array}$ & 200 & 200 & 100 & 1850 \\
\hline $\begin{array}{l}\text { Koliform gru- } \\
\text { bu bakteri sa- } \\
\text { yımı }\end{array}$ & 200 & 56 & 28 & 151 \\
\hline $\begin{array}{l}\text { Koagulas (+) } \\
\text { Staphy.' ların } \\
\text { sayımı }\end{array}$ & 200 & 72 & 36 & 96 \\
\hline $\begin{array}{l}\text { Enterococ.' la- } \\
\text { rın sayımı }\end{array}$ & 200 & 60 & 30 & 82 \\
\hline $\begin{array}{l}\text { Maya-Küflerin } \\
\text { sayımı }\end{array}$ & 200 & 24 & - & 89 \\
\hline $\begin{array}{l}\text { Salmonella- } \\
\text { Shigella }\end{array}$ & 200 & - & 12 & - \\
\hline
\end{tabular}

Getvel 6. Araştırmada ișlenen numunelerin toplu analiz sonuçları

Denemeye alınan 200 adet numunenin 74'ünde küf saptanmıştır.

Koagulas Pozitif Staphylococcus'ların sayımı için CARTER (2) besi yeri kullanılmıştır. Bu besi yerinde mevcut \% 7.5 oranındaki tuz miktarı besi yerinin Coagulase Pozitif Staphylococcus'lar için selektif etkenidir. Bu araştırmada 200 numunenin \% 36'sında üreme tespit edilmiştir.

SINELL ve KUSCH (12) denemeye aldikları 168 et numunesinin \% 12'sinde Coagulase Pozitif Staphylococcus tespit etmişlerdir. ZAGAEVSKII (19) denemeye aldığı 312 adet et numunesinden 76'sında Staphylococcus izole etmiştir. 
200 numunede Salmonella-Shigella grubu mikroorganizma tespit edilememiştir.

$\mathrm{Bu}$ araştırmada incelenen 200 adet et numunesi, kesimden sonra 24 saat dinlendirilmiş daha sonra parçalama dairesine alınmış, parçalanma ve paketlenme işlemlerinden sonra piyasaya arza hazır hale gelen paket etlerden alınmıştır. Yeni kesilen sağlıklı hayvanlara ait gövdeler kesimden hemen sonra hemen hemen steril denecek bir durum arzederler. Bu neden ile paket etlerden alınan numunelerden 200 adedinin hepsinde üremenin görülmesi, kontaminasyonun parçalama dairesinde olduğunu göstermektedir.

\section{BULGULAR}

Bu çalıฺ̧̧ esnasında mahallinde edinilen izlenimlere göre; kesim ve parçalama esnasındaki kontaminasyona;

1- Hayvanların derisi ve kullanılmayan vücut artıkları,

2- Kesim esnasında kullanılan aletler (bıçak v.b.),

3- İşçilerin elleri ve elbiseleri neden olmaktadır.

Bu kontaminasyon kaynakları gözönünde tutularak etlerin daha hijyenik bir şekilde tüketime arz edilmesi için, alınması gereken önlemleri şu şekilde sıralayabiliriz.

1- Gida Maddeleri Tüzüğüne, diğer gida maddelerinde olduğu gibi etler için de hijyenik kaliteyi belirleyecek bakteriyolojik standardlar konulmalıdır.

2- Parça-Paket et hazırlanması esnasında gerek parçalama ve gerekse paketleme dairesinde çalışan personelin sağlık durumu ve burada hijyenik koşullara ait hususlara Gıda Maddeleri Tüzüğünde yer verilmelidir.

3- Parça etin hazırlanması mümkün olduğu kadar modernize edilmeli ve paketleme işlemi, bugün hemen bütün gelişmiş dünya milletlerinde olduğu gibi el değmeden vakumla paketleme sistemine dönüştürülmelidir.

4- Satışa arz edilen etler yine Gıda Maddeleri Tüzüğünde belirtilecek olan bir zaman zarfinda; örneğin 3 gün, bir hafta gibi bakteriyolojik muayene için laboratuvara sevk edilmeli ve ette mevcut mik- 
roorganizma miktarı ve nev'i; tüzük hükümlerinde belirlenecek veçhile devamlı kontrol altında tutularak tüzük hükümlerine uyması sağlanmalidir.

\section{ÖZET}

Bu araştırmada; Et ve BALIK KURUMU, Ankara kombinasında hazırlanarak piyasaya arz edilen parça-paket etlerin hijyenik kalitelerinin mikrobiyolojik yönden analizleri üzerinde çalışılmıştır.

11.5.1972 ile 16.3.1974 tarihleri arasında 200 adet et numunesinde hijyen indeksine dahil mikroorganizmalar ile besin intoksikasyonuna neden olan mikroorganizmalardan; Koagulas Pozitif Staphylococcus ve besin enfeksiyonuna sebep olan mikroorganizmalardan Salmonella-Shigella grubu mikroorganizmalar aranmıştır. Analize tabi tutulan numunelerden elde edilen mikrobiyolojik analizlere ait sonuçlar cetvel (1) de verilmiştir.

Buna göre numunelerde Total Bakteri Sayımı \% 100; Koliform grubu mikroorganizmalar \% 28; Enterotoksijenik Staphylococcus'ler $\% 36$; Str.faecalis $\% 30$; küf ise $\% 12$ oranında müspet bulunmuştur. Enterobacteriaceae'den Salmonella ve Shigella genuslarına ait species'lere tesadüf edilememiştir.

\section{SUMMARY}

The microbiological analysis of pre-packed meat which were marketed by the Meat and Fish Organization, Ankara Slaughterhouse for the consumption as food was carried out in this research.

Between May 111972 and March 161974 two hundred samples of above material were taken for the examination.

Table (1) shows the results of microbiological analysis of samples which were used in this research.

The percentage of Total Count was $100 \%$; Coliforms was 28 $\%$; Coagulase Positive Staphylococcus was $36 \%$; Strep. faecalis was $30 \%$; Moulds was $12 \%$; No Salmonella- Shigella group microorganism was observed. 


\section{LITERATÜR}

1. American Public Health Association., "Recommended Methods for the Microbiological Examination of Foods" 2 nd. ed., A.P.H.A. Inc. New York, (1966).

2. Carter, C.H., 7. Bact. 79, 743. (1960).

3. Difco Manual., Ninth Edition, Detroid I, Michigan, (1953).

4. Frazier, W.C., "Food Microbiology" 2 Ed. Mc Graw Hill book Comp. New York, (1967).

5. Gulustani, A., "A survey of the bacteriological Condition of carcass meat., fac. agric, univ. Kabul-Arch lesens-Nitt. Hyg., 23/8, (1972).

6. Ionescu, Gh., Ienstea, C., Ionescu, C. et al., "Bacteria of the Salmonella genus in refrigerated pork packed in polyethylene bags". Bucuresti-Igiens 18/2, (1969).

7. Lazzara, A. and Priolo, A., "Food poisoning outbreaks caused by meat slaughtered too Quickly"' Ann. Sanita Pubbl., Rev, 28/4, (1969).

8. Omurtag, A.C., "Süt ve mamülleri ile margarin ve sunî yağların Fiziksel, Kimyasal, Mikrobiyolojik, Serolojik ve Biyolojik Analiz Metodları" Ongun Kardeşler Matbaası. Ankara, (1966).

9. Panagiotophoulus, N. and Spanos, G., "A study on the $\mathrm{pH}$ and the total bacterial flora of frozen beef" Hellen Armed Forcess Med. Rev., $4 / 5$ (1970).

10. Production Year Book FAO, Vol. 25. Genova, (1971).

11. Reinbold, G.W., Swern, N.M. and Hussong, R.V., "A plating medium for the isolation and Enumeration of Enterococci" J. Dairy Sci., 36 (1953).

12. Sinel, H.J. and Kusch, D., "Selective culturing of coagulase positive staphylococci flora chopped meat" Berlin Arch. Hyg. 153/1, (1969).

13. Skovgaard, N., "Food hygiene" Royal Vet. Agricul Univ. Copenhagen, Denmark, (1974).

14. Tieceo, G., "Bacteriological tests on minced meda samples on sale in Italy" Archivio Veterinario Italiano, (2), (1972).

15. Timoney, J. and Whelan, C.A., "Salmonella in the Duplin Meat Supply" Irish Vet. J., 23/3, (1969).

16. T.C. Sağlık ve Sosyal Yardım Bakanlığı., Gıda maddelerininUmumi sağhl̆ğı ilgilendiren Eşya ve Levazımın hususi vasıflarını gösteren Tüzük Başkakanlık Mat. Yayını No: 161, (1952).

17. Van Schothorst, M. and Kampelmacher, E.H., "Salmonella meat imported form south American Countries"' 7. Hyg., 65/3, (1967).

18. Wesolowski, Z., Koba, S. and Charczuk, Z., "Mass food poisining caused by Salmonella tyhpimurium in Kielce" 23/3, (1969).

19. Zagaevsky, I.S., "Staphylococcal Contamination of beef" Kaf. Veter. Sanait. Expert., Inst. Balaya Tserkoy No: $31 / 5$, (1972). 